\title{
PENGARUH METODE LATIHAN IMAGERY DAN KONSENTRASI TERHADAP KETEPATAN FLOATING SERVICE ATLET BOLA VOLI
}

\author{
Ari Septiyanto dan Suharjana \\ Program Pascasajana Universitas Negeri Yogyakarta \\ email: ariesep_spd@yahoo.co.id
}

\begin{abstract}
Abstrak: Penelitian bertujuan untuk mengetahui: (1) perbedaan pengaruh antara metode latihan imagery internal dan imagery external terhadap ketepatan floating service bagi atlet yunior putra; (2) perbedaan pengaruh konsentrasi tinggi dan rendah terhadap ketepatan floating service; dan (3) interaksi kedua metode latihan dan konsentrasi terhadap ketepatan floating service. Metode penelitian adalah eksperimen dengan rancangan faktorial $2 \times 2$. Sampel penelitian 36 atlet yang diambil dengan teknik purposif. Instrumen untuk mengukur konsentrasi menggunakan Grid Concentration Test, ketepatan servis bola voli dengan AAHPER Service Accuraccy. Teknik analisis data dengan anova dua jalur. Hasil penelitian menunjukkan: (1) ada perbedaan pengaruh antara metode latihan internal imagery dan external imagery terhadap hasil floating service, metode latihan internal imagery lebih baik dibandingkan dengan metode latihan external imagery, (2) ada perbedaan hasil floating service antara atlet yang memiliki konsentrasi tinggi dan konsentrasi rendah, atlet dengan konsentrasi tinggi lebih baik dibandingkan dengan konsentrasi rendah terhadap hasil floating service, dan (3) ada interaksi antara metode latihan internal imagery dan external imagerydan konsentrasi (rendah dan tinggi) terhadap hasil floatingservice bagi atlet.
\end{abstract}

Kata Kunci: metode latihan, internal imagery, external imagery, ketepatan servis

\section{THE EFFECT OF IMAGERY TRAINING METHOD AND CONCENTRATION ON THE FLOATING SERVICE ACCURACY FOR VOLLEYBALL ATHLETES}

\begin{abstract}
The purposes of this research are three fold, they are (1) to reveal the differences between the effect of internal imagery training method and that of external imagery training method on the Float Serve Accuracy of the junior male volleyball athletes, (2) to reveal the differences between the effect of high concentration and that of low concentration on the Float Serve Accuracy of volleyball athletes, and (3) the interaction between both the training methods and concentration on the Float Serve Accuracy. This experimental research deployed factorial design $2 \times 2$. The samples of this research were 36 athletes who were selected through purposive sampling. The instrument to measure the concentration was Grid Concentration Test and to measure serve was AAHPER Service Accuraccy. The data analyzing technique was two ways ANOVA.The results of the research show that: (1) differences are found between the effect of internal imagery and that of external imagery on the serve performance, internal imagery is considered better than external imagery; (2) differences are found between the serve performance ofthe athletes with high concentration and that of athletes with low concentration, the athletes with high concentration are better than those with low concentration; (3) There is an interaction between training method (internal imagery and external imagery) and concentration (high and low) toward the serve performance of the junior male athletes.
\end{abstract}

Keywords: training method,internal imagery, external imagery, serve accuracy

\section{PENDAHULUAN}

Dekade terakhir ini olahraga bola voli mengalami perubahan dan perkembangan. Perubahan dan perkembangan olahraga bola voli pada satu dekade terakhir ini sangat pesat. Terdapat perbedaan yang jelas antara sistem permainan bola voli lama dengan sistem permainan bola voli modern. Perbedaan tersebut terletak pada peraturan permainan, sistem permainan dan tugas pemain (Muhajir, 2007:124). Perbedaan dalam peraturan permainan bola voli lama adalah meliputi penggunaan sistem poin 15 , servis menyentuh net dinyatakan mati dan tidak menjadi poin untuk tim lawan serta belum adanya spesialisasi pemain. 
Pada peraturan permainan bola voli modern terjadi perubahan. Sistem poin menggunakan rally point, servis mati karena keluar atau meranjau net menjadi poin bagi lawan serta adanya spesialisasi pemain. Pada bola voli modern terdapat spesialisasi pemain meliputi dari libero, defender, dan tipe spiker.

Pada perkembangannya, bola voli di Yogyakarta menjadi salah satu cabang olahraga favorit. Hal tersebut dapat terlihat dari jumlah klub olahraga bola voli yang ada di Yogyakarta. Klub bola voli di DIY antara lain seperti Ge-Lighting, Baja 78, Samudra, Raja Wali, Gajah Loka, Pervas, Garuda, Ganevo, Pendowo, Pervoc, Bima Putra, Wisnu Putra, Spirit, Padmanaba, Raseko, Yuso Gunadarma, Yuso Sleman, Maju Lancar, Dhagsinarga dan JIB Kids. Dengan adanya klub bola voli tersebut tentu saja akan membantu proses pembinaan olahraga bola voli. Dampak dari adanya klub olahraga tersebut tentu salah satunya adalah munculnya atlet-atlet bola voli yang potensial. Salah satu kunci sukses pembinaan olahraga adalah adanya klub-klub olahraga yang membina atlet-atlet secara berjenjang sesuai tingkat usia

Permainan voli akan berjalan baik apabila faktor pendukung permainan tersebut dikuasai dengan baik. Faktor-faktor yang harus dimiliki oleh seorang pemain atau atlet dalam olahraga bola voli di antaranya faktor fisik, teknik, taktik dan mental. Terkait faktor fisik dan teknik tidak lepas dari kemampuan motorik seseorang. Pada dasarnya setiap orang memiliki kemampuan motorik yang berbeda. Kemampuan motorik merupakan karakteristik yang melekat pada diri seseorang (Subarjah, 2010:329). Oleh karena itu,pelaksanaan latihan keempat aspek tersebut harus dilakukan secara teratur, terencana dan berkesinambungan agar dapat meningkatkan prestasi seorang atlet olahraga bola voli. Pada permainan bola voli setiap pemain harus memiliki keterampilan teknik dasar, karena kualitas setiap individu pemain akan mempengaruhi keberhasilan sebuah tim untuk memenangkan suatu pertandingan.

Beutelsthal (2008:8) mengemukakan bahwa teknik adalah prosedur yang telah dikembangkan berdasarkan praktik dan bertujuan mencari penyelesaian suatu problema pergerakan tertentu dengan cara yang paling ekonomis dan berguna. Ahmadi (2007:20) menyatakan bahwa terdapat beberapa teknik dasar dalam permainan bola voli, antara lain: (1) service (pukulan untuk memulai permainan), (2) passing, yang terdiri dari passing bawah dan passing atas (cara mengoper bola), (3) spike/smash (pukulan ke daerah lawan) dan (4) block (bendungan).

Tujuan utama dari teknik-teknik tersebut adalah untuk membuat tim mampu menyusun sebuah serangan dan pola bertahanan sebaik mungkin sehingga dengan serangan dan pertahanan yang baik diharapkan akan menghasilkan angka untuk tim penyerang. Dalam permainan bola voli, servis merupakan salah satu teknik dasar yang paling penting dan harus dikuasai dengan baik oleh setiap atlet. Teknik servis merupakan salah satu teknik dimana seorang atlet menguasai secara penuh bola sebelum melakukan eksekusi gerakan. Teknik servis wajib dikuasai oleh setiap atlet karena teknik ini berguna untuk memulai sebuah permainan sekaligus sebagai sebuah serangan pertama bagi sebuah tim. Servis tidak hanya menjadi sebuah teknik untuk memulai permainan, melainkan senjata pertama untuk mendapatkan poin dalam permainan bola voli (Clemens \& McDowell, 2012:6).

Servis pada permainan bola voli modern dengan menggunakan sistem rally point berkembang menjadi sebuah kunci kesuksesan sebuah tim dalam memenangkan sebuah pertandingan. Servis pada permainan bola voli modern sekarang ini dirancang selain untuk memulai permainan sekaligus bertujuan sebagai serangan pertama. Tujuan servis sekarang ini untuk menyulitkan lawan untuk dalam menerima (receive) dan mematikan lawan langsung untuk mendapatkan poin. Tim yang tersusun dengan karakteristik pemain yang mempunyai passing, smashdan block yang baik belum tentu bisa memenangkan pertandingan tanpa penguasaan teknik servis yang baik.

Banyak keuntungan yang diperoleh dari sebuah tim yang memiliki pemain yang mempunyai penguasaan teknik servis yang baik. Keuntungan dari penguasaan servis antara lain: (1) mampu menekan lawan sejak awal permainan, (2) menghemat tenaga apabila bisa mematikan lawan dari posisi servis, dan (3) meningkatkan kepercayaan diri pemain di lapangan. Selain itu dengan penguasaan teknik servis yang baik dan mampu mematikan lawan akan memberikan waktu istirahat bagi pemain lain yang berada di dalam lapangan karena tidak terjadi permainan sehingga kondisi tim tersebut akan menghemat energi sekaligus kondisi mental yang semakin membaik. Namun hal tersebut akan berbanding terbalik jika 
para atlet dari sebuah tim tidak menguasai teknik servis dengan baik. Lawan akan mudah menyusun sebuah serangan dan mendapatkan poin.

Fakta di lapangan banyak ditemukan seorang pemain baik level junior hingga senior gagal memanfaatkan teknik servis secara optimal. Berdasarkan data dari FIVB sejak olimpiade tahun 2004 penggunaan tipe floating service meningkat $15 \%$ dan pada olimpiade 2008 meningkat 30\%. Floating service menjadi pilihan karena hasil perkenaan pola menjadi sulit diprediksi dan arah yang mengambang (MacKanzie, Kortegaard, LeVangie, et all, 2012: 579). Berdasarkan data di atas dapat diketahui bahwa perkembangan serangan pertama dalam permainan bola voli modern populer menggunakan tipe floating service. Penggunaan tipe floating service karena hasil pukulan servis tersebut sulit untuk diprediksi arah datangnya bola dan menyulitkan lawan dalam melakukan receive. Servis menjadi penting karena menjadi serangan pertama. Tujuannya tidak lain adalah untuk mendapatkan poin.

Perkembangan bola voli di DIY terlihat tipe floating service di level yunior menjadi favorit. Berdasarkan hasil diskusi dengan beberapa pelatih klub bola voli dan obervasi pada beberapa klub di DIY khususnya atlet yunior putra banyak yang menggunakan jenis floating service. Namun terdapat sebuah fakta di lapangan banyak ditemukan atlet yunior putra memiliki akurasi servis yang rendah dan mengalami kegagalan melakukan servis. Hal tersebut berdasarkan pengamatan pada event kejuaraan daerah bola voli antar klub tingkat junior Daerah Istimewa Yogyakarta pada tahun 2014, event kejuaraan POPWIL tahun 2014 di Bali serta diskusi dan sarasehan dari rekan-rekan pelatih klub bola voli di DIY. Pada pelaksanaan kejurda yunior tahun 2014 para pelatih dari klub Yuso Gunadarma, Yuso Sleman, Ganveo dan Baja 78 mencatat dalam setiap set pertandingan kehilangan poin rata-rata 5-8 dari kegagalan servis. Selain itu data dari tim pelatih tim bola voli putra POPWIL DIY pada pelaksaaan POPWIL wilayah III tahun 2014 Bali diketahui dalam setiap set hampir kehilangan 3-5 poin dari servis.

Data tersebut menjadi penguat bahwa prestasi atlet bola voli yunior putra DIY belum mampu bersaing di level nasional. Hal tersebut sangat wajar karena hanya berawal dari sebuah teknik servis yang belum dikuasai dan dimaksimalkan secara baik oleh para atlet. Selain itu pelatih juga mengeluhkan tingkat akurasi servis yang rendah. Esensi tujuan utama dari sebuah servis bola voli modern adalah sebagai serangan. Namun pada kenyataannya servis yang harusnya menjadi serangan pertama dengan mengarahkan kepada pemain yang memiliki receive jelek banyak meleset dari target. Dari hal tersebut tentu terjadi kesenjangan antara instruksi pelatih terhadap target yang dituju dengan hasil eksekusi atlet dilapangan. Kesenjangan implementasi teknik floating service khususnya dalam tingkat akurasi yang rendah perlu dibenahi pada sesi latihan.

Terdapat banyak faktor yang menjadi penyebab rendahnya tingkat akurasi servis dan gagal dalam mengeksekusi servis. Atlet yunior dalam melakukan eksekusi gerakan terkesan tergesa-gesa, sikap awal yang salah, rangkaian gerakan yang tidak ritmis, perkenaan tangan pada bola tidak tepat, konsentrasi yang buyar, target servis yang tidak tepat, tingkat akurasi rendah dan kurang konsisten pada hasil yang diperoleh. Banyak atlet yunior pada saat berlatih servis tidak berkonsentrasi secara baik terhadap rangkaian gerak dan tujuan servis. Atlet tidak memaksimalkan waktu berlatih servis untuk melatih konsentrasi dan mengarahkan pada target. Atlet hanya asal melakukan gerakan teknik servis dan tidak memaksimalkan waktu untuk berkonsentrasi terhadap rangkaian gerak serta arah target servis. Alhasil pada saat berlatih atlet tidak mendapatkan sebuah otomatisasi rangkaian gerak floating service yang benar.

Inkonsistensi tingkat keberhasilan serta akurasi floating service yang rendah oleh atlet junior pada saat berlatih dan bertanding. Hal itu mengindikasikan bahwa konsentrasi atlet pada saat akan melakukan teknik servis belum terbentuk dan belum stabil. Padahal, berdasarkan kualitas teknik setiap atlet mampu menguasai teknik servis dengan baik. Hal ini terjadi karena tingkat perhatian dan konsentrasi atlet menurun atau terganggu bila ada beberapa rangsang yang muncul bersamaan (Sukadiyanto, 2006: 162). Upaya peningkatan konsistensi konsentrasi atlet dalam melakukan floating service dan tingkat akurasi membaik perlu diberikan program latihan mental. Latihan mental disini bertujuan untuk mengelola perhatian dan konsentrasi atlet yang mengarah pada konsentrasi teknik servis sehingga dapat meningkatkan prosentase keberhasilan dan akurasi dari floating service.

Dalam pelaksanaan latihan mental terdapat berbagai macam jenis metode latihan.Wiernberg 
\& Gould (2007: 296) mengemukakan bahwa latihan mental mencakup imagery, vizualitation, mental rehearsal, symbolic rehearsal, covert practice dan mental practice. Dalam program latihan mental ada latihan yang disebut imajeri. Imajeri adalah suatu simulasi yang terjadi dalam otak yang menyebabkan individu dapat membentuk gambar-gambar dalam otaknya (Mardhika, 2015: 108). Martens (William, 1993:202) menyatakan bahwa imagery merupakan teknik yang efektif untuk meningkatkan performa dalam berbagai keterampilan olahraga antara lain tembakan bebas bolabasket, tendangan hukuman sepakbola, teknik karate, servis bola voli, servis tenis, dan golf. Latihan mental imagery merupakan serangkaian proses pembinaan mental atlet dengan melibatkan unsur semua panca indera untuk meningkatkan konsentrasi, mengarahkan tindakan ke suatu tujuan sesuai rencana, pengendalian emosi dan psikofisik.

Terdapat dua jenis perspektif atau pandangan, yaitu imagery internal perspective dan imagery external perspective (Wienberg \& Gould, 2007:301). Pelaksanaannya kedua jenis latihan tersebut memerlukan sebuah pendampingan. Terkait model imagery external perspective membutuhkan stimulus dari luar berupa video atau gambar yang bertujuan untuk membantu atlet berkonsentrasi pada sebuah teknik servis. Harapannya dengan adanya latihan mental melalui metode imagery internal perspective dan imagery external perspective akan dapat membantu atlet bola voli putra junior dalam meningkatkan konsentrasi dalam melakukan teknik servis atas yang memiliki tingkat akurasi yang baik.

Berdasarkan permasalahan di atas, perlu dilakukan penelitian terhadap kemampuan teknik floating service atlet bola voli putra junior dengan memberikan dua bentuk latihan mental imagery yaitu, latihan internal imagery dan external imagery. Diharapkan dengan adanya bentuk latihan tersebut akan memperbaiki konsentrasi atlet pada saat akan melakukan floating service dan menghasilkan tingkat akurasi yang tinggi. Sampai saat ini belum populer digunakan bentuk latihan mental imagery yang dikombinasikan dengan latihan teknik untuk meningkatkan kualitas sebuah teknik khususnya floating service pada cabang bola voli.

\section{METODE}

Metode yang digunakan dalam penelitian ini adalah metode eksperimen faktorial. Masingmasing faktor terdiri dari dua buah taraf, dengan menggunakan tes awal dan tes akhir. Populasi adalah atlet klub bola voli yunior putra Daerah Istimewa Yogyakarta (DIY) yang berjumlah 36 atlet. Sampel ditentukan dengan teknik purposif. Penentuan sampel antara lain dengan pertimbangan atlet yunior putra yang berumur antara 14 tahun sampai dengan 19 tahun dari klub bola voli Yuso Sleman dan Yuso Gunadarma dan hasil tes konsentrasi, untuk menggolongkan atlet yang memiliki konsentrasi tinggi dan rendah.

Instrumen pengumpul data dalam penelitian ini menggunakan tes konsentrasi (Grid Concentration Test) dan tes ketepatan servis atas dari AAHPER Service Test. Grid Concentration Test merupakan salah satu bentuk alat ukur untuk mengetahui tingkat konsentrasi dengan menggunakan angka Harris \& Harris (Thelwell, 2006:32) dan Wienberg \& Gould (2007:391). Tes ketepatan servis atas ini modifikasi dari tes AAHPER Servis Test. Tes ini bertujuan untuk mengukur ketepatan teknik servis atas, dalam kaitannya terhadap ketepatan mengarahkan bola pada kesasaran tertentu. Tes menggunakan instrumen tes ketepatan servis atas modifikasi dari tes AAHPER serving test. Instrumen tersebut memiliki validitas sebesar 0,867 dan reliabilitas sebesar 0,768 . Instrumen tes tersebut dimodifikasi guna menyesuaikan dengan peraturan voli terbaru dan karakteristik dari subjek penelitian, yaitu atlet yunior putra.

Teknik analisis data yang digunakan adalahteknik anava dua jalur dengan bantuan SPSS version dengan taraf signifikansi $\alpha=0,05$. Selanjutnya untuk membandingkan pasangan rata-rata perlakuan digunakan uji Rentang Newman Keuls (Sudjana, 2002: 36-40).Sebelumnya, dilakukan uji persyaratan yaitu meliputi uji normalitas dan uji homogenitas varians.

\section{HASIL DAN PEMBAHASAN Hasil}

Data hasil penelitian ini adalah berupa data postes yang merupakan gambaran umum tentang masing-masing variabel yang terkait dalam penelitian.Data pretesdan postes hasil tes ketepatanfloating service bola voli disajikan pada Tabel 1. Tabel 2.

Hasil uji normalitas data disajikan pada 
Tabel 1. Hasil Pretes dan Postes Hasil Tes Ketepatan Servis Bola Voli

\begin{tabular}{ccllll}
\hline \multirow{2}{*}{ Metode } & Tingkat & \multicolumn{2}{c}{ Pretes } & \multicolumn{2}{c}{ Postes } \\
& Konsentrasi & Statistik & Hasil & Statistik & Hasil \\
\hline \multirow{2}{*}{ Imagery } & Tinggi & Jumlah & 123.00 & Jumlah & 142.00 \\
external & & Rerata & 24.6000 & Rerata & 28.4000 \\
& & SD & 2.96648 & SD & 3.04959 \\
& \multirow{2}{*}{ Rendah } & Jumlah & 80.00 & Jumlah & 97.00 \\
& & Rerata & 16.0000 & Rerata & 19.4000 \\
& \multirow{2}{*}{ Tinggi } & SD & 1.41421 & SD & 1.14018 \\
& & Jumlah & 118.00 & Jumlah & 162.00 \\
Imagery & & Rerata & 23.6000 & Rerata & 32.4000 \\
internal & \multirow{2}{*}{ Rendah } & SD & 1.67332 & SD & 2.30217 \\
& & Jumlah & 78.00 & Jumlah & 104.00 \\
& & Rerata & 15.6000 & Rerata & 20.8000 \\
& & SD & 2.19089 & SD & 2.68328 \\
\hline
\end{tabular}

Tabel 2. Uji Normalitas

\begin{tabular}{lrll}
\hline \multicolumn{1}{c}{ Data } & $\mathrm{p}$ & $\begin{array}{c}\text { Taraf } \\
\text { Signifikasi }\end{array}$ & Keterangan \\
\hline Pretes Eksternal Konsentrasi Tinggi & 0,823 & & \\
Postes Eksternal Konsentrasi Tinggi & 0,997 & & Normal \\
Pretes Eksternal Konsentrasi Rendah & 0,535 & 0,05 & \\
Postes Eksternal Konsentrasi Rendah & 0,941 & & \\
Pretes Internal Kosentrasi Tinggi & 0,953 & & \\
Postes Internal Konsentrasi Tinggi & 0,952 & & \\
Pretes Internal Konsentrasi Rendah & 0,492 & & \\
Postes Internal Konsentrasi Rendah & 0,851 & & \\
\hline
\end{tabular}

Hasil uji homogenitas disajikan pada Tabel 3.

Tabel 3. Uji Homogenitas

\begin{tabular}{crrrrr}
\hline Kelompok & $\begin{array}{c}\text { Levene } \\
\text { Statistic }\end{array}$ & df1 & df2 & Sig. & Keterangan \\
\hline Pretes & .110 & 1 & 18 & 0,744 & Homogen \\
Postes & .110 & 1 & 18 & 0,216 & Homogen \\
\hline
\end{tabular}

\section{Pengujian Hipotesis}

Hipotesis yang pertama "Ada perbedaan pengaruh antara metode latihan internal imagery dan metode latihan external imagery terhadap hasilfloating service bagi atlet klub bola voli yunior putra DIY".Hasil analisis data yang untuk mengujihipotesis tersebut ditunjukkan padaTabel 4.

Tabel 4. Hasil Anova Kelompok Eksperimen Metode Latihan Internal Imagery dan Metode Latihan External Imagery

\begin{tabular}{lrrrrr}
\hline Source & $\begin{array}{c}\text { Type III } \\
\text { Sum of } \\
\text { Squares }\end{array}$ & df & $\begin{array}{c}\text { Mean } \\
\text { Square }\end{array}$ & $\boldsymbol{F}$ & Sig \\
\hline $\begin{array}{l}\text { Metode } \\
\text { Latihan }\end{array}$ & 20.000 & 1 & 20.000 & 4.938 & 0.041 \\
\hline
\end{tabular}

Hasil analisis data menunjukkan bahwa hipotesis diterima.

Hipotesis kedua yang berbunyi "Ada perbedaan hasil floating service antara atlet yang memiliki konsentrasi tinggi dan konsentrasi rendah bagi atlet klub bola voli yunior putra D.I Yogyakarta". Hasil analisis data disajikan pada Tabel 5.

Tabel 5. AnalisisPerbedaan Hasil Floating Service antara Atlet yang Memiliki Konsentrasi Tinggi dan Konsentrasi Rendah

\begin{tabular}{|c|c|c|c|c|c|}
\hline Source & $\begin{array}{l}\text { Type III } \\
\text { Sum of } \\
\text { Squares }\end{array}$ & $d f$ & $\begin{array}{l}\text { Mean } \\
\text { Square }\end{array}$ & $F$ & Sig \\
\hline Konsentrasi & 605.000 & 1 & 605.000 & 149.383 & 0.000 \\
\hline
\end{tabular}

Hasil analisis data menunjukkan bahwa hipotesis diterima.

Hipotesis ketiga yang berbunyi "Ada interaksi antara metode latihan (internal imagery dan external imagery) dan konsentrasi (rendah dan tinggi) terhadap hasil floating service bagi atlet klub bola voli yunior putra D.I Yogyakarta".Hasil analisis data disajikan pada Tabel 6. 
Tabel 6. Analisis Interaksi antara Metode Latihan (Internal Imagery dan External Imagery) dan Konsentrasi

\begin{tabular}{cccccc}
\hline Source & $\begin{array}{c}\text { Type III } \\
\text { Sum of } \\
\text { Squares }\end{array}$ & df & $\begin{array}{c}\text { Mean } \\
\text { Square }\end{array}$ & F & Sig \\
\hline $\begin{array}{l}\text { Metode latihan } \\
\text { *Konsentrasi }\end{array}$ & 20,000 & 1 & 20,000 & 4,938 & 0,041 \\
\hline
\end{tabular}

Hasil analisis data menunjukkan bahwa hipotesis diterima. Hal itu berarti terdapat interaksi antara metode latihan (internal imagery dan external imagery) dan konsentrasi (rendah dan tinggi) terhadap hasil floating service bola voli.

Hasil uji Tukey pada tanda asterisk (*) menunjukkan bahwa pasangan-pasangan yang memiliki interaksi atau pasangan yang berbeda secara nyata (signifikan) adalah: (1) a2b1-a2b2, (2) a2b1-a1b2, (3) a2b2-a2b1, (3) a2b2-a1b1, (4) a1b1-a2b2, (5) a1b1-a1b2, (6) a1b2-a2b1, (7) alb2-a1b1. Hal itu dapat disimpulkan sebagai berikut. (1) Jika metode latihan external imagery dengan konsentrasi tinggi dipasangkan dengan metode latihan external imagery dengan konsentrasi rendah,terdapat perbedaan pengaruh yang signifikan. (2) Jika metode latihan external imagery dengan konsentrasi tinggi dipasangkan dengan metode latihan internal imagery dengan konsentrasi rendah, terdapat perbedaan pengaruh yang signifikan. (3) Jika metode latihan external imagery dengan konsentrasi rendah dipasangkan dengan metode latihan external imagerydengan konsentrasi tinggi,terdapat perbedaan pengaruh yang signifikan. (4) Jika metode latihan external imagery dengan konsentrasi rendah dipasangkan dengan metode latihan internal imagery dengan konsentrasi tinggi,terdapat perbedaan pengaruh yang signifikan. (5) Jika metode latihan internal imagery dengan konsentrasi tinggi dipasangkan dengan metode latihan external imagery dengan konsentrasi rendah terdapat perbedaan pengaruh yang signifikan. (6) Jika metode latihan internal imagery dengan konsentrasi tinggi dipasangkan dengan metode latihan internal imagery dengan konsentrasi rendah,terdapat perbedaan pengaruh yang signifikan. (7) Jika metode latihan internal imagery dengan konsentrasi rendah dipasangkan dengan metode latihan internal imagery dengan konsentrasi tinggi, terdapat perbedaan pengaruh yang signifikan.
Pasangan-pasangan lainnya dinyatakan tidak memiliki perbedaan pengaruh adalah: (1) a2b1-a1b1, (2) a2b2-a1b2, (3) a2b2-a1b2, (4) $\mathrm{a} 1 \mathrm{~b} 1-\mathrm{a} 2 \mathrm{~b} 1,(5) \mathrm{a} 1 \mathrm{~b} 2-\mathrm{a} 2 \mathrm{~b} 2$. Dengan demikian dapat disimpulkan bahwa sebagai berikut. Pertama, Jika metode latihan external imagery dengan konsentrasi tinggi dipasangkan dengan metode latihan internal imagery dengan konsentrasi tinggi, tidak terdapat perbedaan pengaruh yang signifikan. Kedua, Jika metode latihan external imagery dengan konsentrasi rendah dipasangkan dengan metode latihan internal imagery dengan konsentrasi rendah, tidak terdapat perbedaan pengaruh yang signifikan. Ketiga, Jika metode latihan external imagery dengan konsentrasi rendah dipasangkan dengan metode latihan internal imagery dengan konsentrasi rendah, tidak terdapat perbedaan pengaruh yang signifikan. Keempat, Jika metode latihan internal imagery dengan konsentrasi tinggi dipasangkan dengan metode latihan external imagery dengan konsentrasi tinggi, tidak terdapat perbedaan pengaruh yang signifikan. Kelima, Jika metode latihan internal imagery dengan konsentrasi rendah dipasangkan dengan metode latihan external imagery dengan konsentrasi rendah, tidak terdapat perbedaan pengaruh yang signifikan.

Hasil analisis varian berpasangan dengan uji lanjut Tukey menunjukkan bahwa terdapattujuh pasangan yang berbeda secara signifikan, yaitu: pasangan (1) a2b1-a2b2, (2) a $2 \mathrm{~b} 1-\mathrm{a} 1 \mathrm{~b} 2$, (3) a $2 \mathrm{~b} 2-a 2 b 1$, (3) a $2 b 2-a 1 b 1$, (4) a $1 b 1-a 2 b 2$, (5) a1b1-a1b2, (6) a1b2-a2b1, (7) a1b2-a1b1. Sedangkan pasangan lainnya dinyatakan tidak ada perbedaan yaitu: pasangan (1) a $2 \mathrm{~b} 1-\mathrm{a} 1 \mathrm{~b} 1$, (2) a2b2-a1b2, (3) a2b2-a1b2, (4) a1b1-a2b1, (5) alb2-a2b2.

\section{Pembahasan}

Pembahasan hasil penelitian ini memberikan penafsiran yang lebih lanjut mengenai hasilhasil analisis data yang telah dikemukakan.Hasil pengujian hipotesis menghasilkan dua kelompok kesimpulan analisis yaitu: (1) ada perbedaan pengaruh yang bermakna antara faktor-faktor utama penelitian; dan (2) tidak ada interaksi yang bermakna antara faktor-faktor utama dalam bentuk interaksi dua faktor. Kelompok kesimpulan analisis tersebut dapat dipaparkan lebih lanjut sebagai berikut. 
Perbedaan Pengaruh antara Metode Latihan Internal Imagery dan Metode Latihan External Imagery terhadap Hasil Floating Service Bola Voli

Berdasarkan pengujian hipotesis pertama diketahui bahwa metode latihan internal imagery dan metode latihan external imagery memiliki perbedaan pengaruh yang signifikan dalam meningkatkan hasil floating service bola voli. Perbedaan pengaruh ini didapatkan dari hasil penggunaan metode latihan internal imagery dan metode latihan external imagery tersebut dalam latihan service bola voli. Metode latihan internal imagery terbukti lebih efektif dalam meningkatkan konsentrasi dan ketepatan floating service atas bagi atlet junior. Hal tersebut sesuai dengan teori bahwa latihan imagery dapat meningkatkan performa atlet (Olsson, 2008:133).

Selain itu, berdasarkan data penelitian dapat diketahui bahwa metode latihan internal imagery paling baik dalam meningkatkan akurasi teknik servis. Metode latihan internal imagery terbukti lebih baik dalam meningkatkan performa atlet (Hinshaw dalam Wann, 1997:234). Selain itu, internal imagery lebih tinggi menghasilkan respon psikologis (Olsson, 2008:12). Respon psikologis tersebut mampu menghasilkan hormon endorphin lebih banyak sehingga memberi efek lebih tenang dan nyaman pada atlet saat berlatih. Dengan adanya peran hormon endorphin tersebut tentu membantu atlet lebih berkonsentrasi.

Terkait dengan beberapa teori di atas dapat diketahui bahwa metode latihan internal imagery memiliki beberapa keunggulan dibanding metode latihan external imagery. Dalam metode latihan internal imagery terdapat keunggulan yaitu lebih banyak dalam meningkatkan respon psikologis. Selain itu proses latihan imagery internal juga lebih sederhana dan memaksimalkan pengalaman gerak setiap atlet. Dengan beberapa keunggulan tersebut maka sangat logis jika metode latihan internal imagery diberikan pada atlet dan kemampuan atlet meningkat.

\section{Perbedaan Pengaruh Metode Latihan Imagery Internal dan Imagery External Bagi Atlet yang Memiliki Konsentrasi Tinggi dan Konsentrasi Rendah}

Konsentrasi memiliki peranan penting dalam mempengaruhi sebuah teknik yang dilakukan ataupun hasil sebuah pertandingan olahraga. Perhatian dan konsentrasi sering diartikan sama padahal memiliki definisi yang berbeda. Menurut Sukadiyanto (2006: 161) perhatian adalah merupakan proses kesadaran langsung terhadap informasi (rangsang) yang diterima untuk memutuskan suatu tindakan (respons). Sedangkan konsentrasi adalah adalah kemampuan seseorang untuk memusatkan perhatian pada rangsang yang dipilih (satu objek) dalam waktu tertentu. Schmid \& Peper (Satiadarma, 2000:228) mengemukakan bahwa konsentrasi merupakan hal yang amat penting bagi seorang atlet dalam menampilkan kinerja performa di lapangan. Komponen utama konsentrasi adalah kemampuan untuk memusatkan perhatian pada suatu hal tertentu dan tidak terganggu oleh stimulus internal maupun stimulus eksternal yang tidak relevan.

Dalam permainan bola voli konsentrasi sangat berpengaruh terhadap hasil sebuah teknik yang dilakukan. Dalam hal ini teknik servis erat dengan kontribusi konsentrasi dari atlet tersebut. Teknik servis merupakan salah satu teknik dimana seorang pemain menguasai bola secara penuh dan dapat mengarahkan ke berbagai posisi lapangan. Untuk dapat mengarahkan ke berbagai posisi selain penguasaan teknik yang baik juga didukung oleh tingkat konsentrasi atlet tersebut. Konsentrasi yang baik dan terjaga akan membantu seorang atlet melaksanakan eksekusi teknik dengan baik. Maka berdasarkan penelitian diketahui bahwa atlet yang memiliki tingkat konsentrasi tinggi memiliki kualitas serta peningkatan hasil servis atas.

\section{Interaksi Antara Metode Latihan (Internal Im- agery dan External Imagery) dan Konsentrasi (Rendah dan Tinggi) terhadap Hasil Floating Service}

Berdasarkan hasil yang telah dikemukakan pada hasil penelitian ini bahwa terdapat interaksi yang berarti antara metode latihan (internal imagery dan external imagery) dan konsentrasi terhadap ketepatan servis atas atlet bola voli yunior. Dari tabel yang disajikan bentuk interaksi nampak bahwa faktor-faktor utama penelitian dalam bentuk dua faktor menunjukkan interaksi yang signifikan.Dalam hasil penelitian ini interaksi yang memiliki arti bahwa setiap sel atau kelompok terdapat perbedaan pengaruh setiap kelompok yang dipasang-pasangkan. Berdasarkan hasil penelitian yang didapat bahwa kelompok atlet dengan konsentrasi tinggi dilatih dengan metode internal imagery (a1b1) mengalami peningkatan 
terbesar, urutan ke dua (2) kelompok atlet dengan konsentrasi rendah dilatih dengan metode internal imagery (a1b2), urutan ke tiga (3) kelompok atlet dengan konsentrasi tinggi dilatih dengan metode external imagery (a2b1), urutan ke empat (4) kelompok atlet dengan konsentrasi rendah dilatih dengan metode external imagery (a2b2).

Dari pembahasan tersebut, untuk mengoptimalkan teknik servis atas tipe float bagi atlet bola voli yunior, apabila diketahui atlet tersebut memiliki konsentrasi tinggi cocok dilatih dengan metode internal imagery. Hal ini dikarenakan imagery internal latihannya cenderung lebih sederhana sebab hanya memasukkan satu aspek proses keterampilan memunculkan bayangan teknik servis dalam pikiran atlet. Setelah itu atlet menguatkan gambaran terkait teknik servis didalam pikiran secara berulang kemudian dipraktikkan dalam latihan servis. Seperti yang diungkapkan oleh Wiernberg \& Gould (2007:303-304) bahwa terdapat beberapa teori yang mendukung penampilan efek dari latihan imagery.

Terdapat tiga teori terkait fungsi kerja latihan imagery. Salah satu teori tersebut adalah teori fungsi psychoneuromuscular. Teori ini menyatakan imagery merupakan hasil dari pola subliminal neuromuskular yang serupa dengan pola neuromuskuler yang digunakan pada pergerakan sebenarnya. Meskipun pada saat berlatih tidak menggerakkan otot secara aktif namun perintah dari otak menuju otot tetap terkirim. Sistem neuromuskular memberi kesempatan untuk "melatih" pola pergerakan tanpa menggerakkan otot yang sebenarnya. Artinya bahwa ketika seorang atlet membayangkan sebuah gerakan maka otot-otot yang bekerja pada gerakan tersebut akan terlatih meskipun pasif dan tidak melakukan gerakan secara aktif.

Selain itu, beberapa penelitian menunjukkan latihan internal imagery lebih cocok digunakan untuk atlet elit. Internal imagery lebih bagus dan tepat digunakan untuk open skills (Wiernberg \& Gould, 2003: 289). Keterampilan terbuka yaitu jenis keterampilan yang kondisi lingkungan di sekitar pertandingan sulit untuk dikendalikan dan diperkirakan Schmidt \& Wriesberg (Sukadiyanto, 2006:166). Artinya, posisi lawan dan sasaran bergerak aktif atau aktivitasnya dipengaruhi oleh orang lain atau sebuah rintangan.

Terkait dengan teknik servis dalam bola voli maka teknik tersebut masuk dalam open skills. Artinya dalam proses pelaksanaan dipen- garuhi orang lain atau sebuah rintangan. Kaitannya dengan fungsi penggunaan internal imagery yang lebih banyak menghasilkan psychoneuromuscular maka akan lebih membantu atlet dalam membantu berkonsentrasi. Jadi kesimpulannya bahwa latihan internal imagery lebih tepat digunakan untuk membantu atlet berlatih konsentrasi dalam melakukan teknik servis.

\section{SIMPULAN}

Berdasarkan hasil penelitian dan hasil analisis data yang telah dilakukan, diperoleh kesimpulan sebagai berikut. (1) Ada perbedaan pengaruh antara metode latihan internal imagery dan metode latihan external imagery terhadap hasilfloating service bagi atlet klub bola voli yunior putra DIY. Metode latihan yang memiki hasil yang paling baik dalam meningkatkan hasil floating service adalah metode internal imagery.(2) Ada perbedaan hasil floating service antara atlet yang memiliki konsentrasi tinggi dan konsentrasi rendah bagi atlet klub bola voli yunior putra DIY. Atlet yang memiliki konsentrasi tinggi lebih baik daripada atlet yang memiliki konsentrasi rendah. (3) Ada interaksi antara metode latihan (internal imagery dan external imagery) dan konsentrasi (rendah dan tinggi) terhadap hasilfloating service bagi atlet klub bola voli yunior putra DIY.

Pasangan-pasangan yang memiliki interaksi atau pasangan yang berbeda secara nyata adalah sebagai berikut. (1) Jika metode latihan external imagery dengan konsentrasi tinggi dipasangkan dengan metode latihan internal imagery dengan konsentrasi tinggi, tidak terdapat perbedaan pengaruh yang signifikan. (2) Jika metode latihan external imagery dengan konsentrasi rendah dipasangkan dengan metode latihan internal imagery dengan konsentrasi rendah, tidak terdapat perbedaan pengaruh yang signifikan. (3)Jika metode latihan external imagery dengan konsentrasi rendah dipasangkan dengan metode latihan internal imagery dengan konsentrasi rendah, tidak terdapat perbedaan pengaruh yang signifikan. (4) Jika metode latihan internal imagery dengan konsentrasi tinggi dipasangkan dengan metode latihan external imagery dengan konsentrasi tinggi tidak terdapat perbedaan pengaruh yang signifikan. (5) Jika metode latihan internal imagery dengan konsentrasi rendah dipasangkan dengan metode latihan external imagery dengan konsentrasi rendah, tidak terdapat perbedaan pengaruh yang signifikan. 


\section{UCAPAN TERIMA KASIH}

Penulis menyampaikan terima kasih kepada Prof. Dr. Suharjana, M.Kes selaku Kaprodi Ilmu Keolahragaan Program Pasca Sarjana UNY serta tim redaksi Jurnal Cakrawala Pendidikan UNY yang telah membimbing dan mengarahkan dalam penulisan jurnal ini.

\section{DAFTAR PUSTAKA}

Ahmadi, N. 2007. Panduan Olahraga Bolavoli. Solo. Pustaka Utama.

Beutelstahl, D. 2008. Belajar Bermain Bolavoli. Bandung. Pionir Jaya.

Clemens, T \& McDowell, J. 2012. The American Volleyball Coach (AVCA). United States. Human Kinetics.

MacKenzie, S., Kortegaard, K., LeVangie, M., et al. "Evaluation of Two Methods of the Jump Float Serve in Volleyball". 2012. Journal of Applied Biomechanics. 2012. 2B,579-586. Human Kinetics.

Mardhika, R., \& Dimyati, D. 2015. Pengaruh Latihan Mental dan Keyakinan Diri terhadap Keberhasilan Tendangan Penalti Pemain Sepak Bola. Jurnal Keolahragaan, 3(1), $106-116$.

Muhajir. 2007. Pendidikan Jasmani Kesehatan dan Rekreasi. Jakarta. Erlangga.

Olsson, C.-J. 2008. Imaging Imagining Actions. Doctoral dissertation from the Department of Integrative Medical Biology, section for Physiology, Umeå University, S-901
87 Umeå, Sweden.ISBN: 978-91-7264658-2.

Satiadarma, P.M. 2000. Dasar-dasar Psikologi Olahraga. Jakarta. Pustaka Sinar Harapan.

Subarjah, Herman. 2010. "Hasil Belajar Keterampilan Bermain Bulutangkis: Studi Eksperimen pada Siswa Diklat Bulutangkis FPOK-UPI". Jurnal Ilmiah Pendidikan. No 3 hal 325-340.

Sudjana.2002. Desain dan Analisis Eksperimen. Bandung: Tarsito.

Sukadiyanto.2006. Konsentrasi dalam Olahraga. Yogyakarta. Majalah Ilmiah Olahraga, FIK UNY Volume 12 April 2006.

Thelwell, R. 2006. Examining the Efficacy of the Concentration Grid Exercise as a Concentration Enhancement Exercise. Journal Psychology of Sport and Exercise: pp. 29-39).

Wann, D.L. 1997. Sport Psychology. United States. Prentice Hall.

Weinberg, R.S. and Gould, Da. 2003. Third Edition: Foundations of Sport and Exercise Psychology. United States: Human Kinetics.

Weinberg, R.S. and Gould, D. 2007. Fourth Edition: Foundations of Sport and Exercise Psychology. United States: Human Kinetics. 